\title{
Motivasi Anggota Klub Gowes Lintau Buo dalam Berolahraga Sepeda
}

\author{
Nurul Hafizah ${ }^{1}$, Hendri Irawadi², Romi Mardela ${ }^{3}$ \\ 1,2,3 Program Studi Pendidikan Kepelatihan Olahraga, Fakultas Ilmu Keolahragaan, \\ Universitas Negeri Padang, Indonesia
}

\section{Informasi Artikel}

Diterima 2021-06-07

Direvisi 2021-06-29

Dipublikasikan 2021-07-10

\section{Keyword:}

Motivasi

Berolahraga Sepeda

\begin{abstract}
Masalah dalam penelitian ini yaitu belum diketahui berapa besar motivasi anggota klub gowes Lintau Buo dalam berolahraga sepeda. Jenis penelitian ini adalah kuantitatif dengan menggunakan metode deskriptif. Populasi dalam penelitian ini berjumlah 50 orang. Teknik pengambilan sampel menggunakan porposif sampling. Hasil penelitian diperoleh bahwa; (1) Tingkat motivasi instrinsik Anggota Klub Gowes Lintau Buo dalam olahraga sepeda, secara intrinsik berada pada kategori tinggi dengan tingkat capaian responden (TCR) 76,16\%, (2) Tingkat motivasi ekstrinsik Anggota Klub Gowes Lintau Buo dalam olahraga sepeda, secara ekstrinsik berada pada kategori tinggi dengan tingkat capaian responden (TCR) 75,86\%, dan (3) secara keseluruan tingkat motivasi Anggota Klub Gowes Lintau Buo dalam olahraga sepeda berada pada kategori tinggi dengan tingkat capaian responden (TCR) 76,06\%, dengan demikian dapat disimpulkan bahwa, tingkat motivasi Anggota Klub Gowes Lintau Buo dalam olahraga sepeda terbilang tinggi.
\end{abstract}

(C) 2020 The Authors. Published by Universitas Negeri Padang.

This is an open access article under the CC BY-NC-SA license (https://creativecommons.org/licenses/by-nc-sa/4.0/

Penulis Korespondensi:

Nurul Hafizah

Universitas Negeri Padang

Email:hafizahnurul444@gmail.com

\section{PENDAHULUAN}

Menurut Bompa di dalam Heru Syarli dan Endang Pati (2017) mengatakan aktivitas olahraga yang dilakukan oleh seseorang dapat menyebabkan perubahan anatomi, fisiologis, biokimia dan psikologis. Efisiensi dari aktivitas fisik tersebut merupakan kombinasi volume (durasi, jarak, dan jumlah repetisi), intensitas (beban dan kecepatan) dan frekuensi dari latihan. Olahragamerupakan fisik yang berulang dan bertujuan untuk memelihara, meningkatkan dan mengekspresikan kebugaran. Ketika seorang pelatih ingin membuat program latihan maka perlu diperhatikan aspek-aspek tersebut.

Kegiatan olahraga juga melibatkan emosi orang yang berpartisipasi di dalamnya secara intens dan merupakan pertalian antara keterampilan, kognitif, sikap, dan nilai-nilai. Huizinga, seorang tokoh antropologi olahraga, mendeskripsikan permainan yang merupakan inti dari olahraga sebagai sebuah kehidupan nyata yang di tempatkan dalam situasi kegiatan temporer dengan segala karakteristik yang ada di dalamnya (Eko Purnomo, 2018).

Indonesia adalah salah satu Negara dengan angka kematian tertinggi karena COVID-19 dengan angka mencapai 8,9\% pada akhir Maret 2020. Kasus kematian karena COVID-19 di Indonesia bahkan lebih tinggi lagi jika dibandingkan dengan China yang hanya $4 \%$. Padahal China 
adalah negara di mana COVID-19 pertama kali ditemukan (Setiati \& Azwar,2020). Angka kematian yang tinggi karena COVID-19 diduga karena kesehatan fasilitas di Indonesia belum siap menangani pasien yang terinfeksi COVID-19. (Encup Supriana, 2020).

Kebanyakan penderita biasa virus corona sembuh secara spontan atau diobati berdasarkan tingkat keparahan gejalanya dengan terapi antivirus konvensional (disebut terapi suportif) atau dengan pemberian mekanis dukungan pernapasan. Beragam obat yang sudah digunakan dan obat percobaan kemungkinan besar berguna untuk pengobatan pasien Covid-19 telah diidentifikasi dalam beberapa bulan terakhir. (Luigi Cirrincione, 2020).

Bersepeda adalah sebuah kegiatan rekreasi atau olahraga, serta merupakan salah satu sarana transportasi darat yang menggunakan sepeda. Banyak penggemar bersepeda yang melakukan kegiatan tersebut di berbagai macam medan, misalnya bukit-bukit, medan yang terjal, jalan raya maupun hanya sekedar berlomba kecepatan saja.

Bersepeda dapat membantu untuk meningkatkan kebugaran, sementara menikmati kebebasan jalan yang terbuka. Bersepeda merupakan salah satu bentuk latihan aerobic yang terbaik (Chris Carmichael-Edmund R. Burke,2003:3). Memilih sepeda untuk dijadikan alat transportasi harian dan mengurangi perjalanan dengan menggunakan kendaraan bermotor, megurangi biaya pemeliharaan jalan, serta berkontribusi untuk mencegah kemacetan. Meskipun sekarang ini bersepeda sepertinya sudah tidak banyak yang melakukan, hal ini karena kemajuan otomotif dengan kehadiran kendaraan roda dua yang lain seperti sepeda motor yang membuat lebih mudah dalam mencapai tempat tujuan dan bertambah lagi adanya mobil maupun kendaraan umum untuk mencapai suatu tempat yang ingin dituju (Sandi Akbar Romadhon).

Sepeda adalah kendaraan beroda dua atau tiga, mempunyai setang, tempat duduk, dan sepasang pengayuh yang digerakkan kaki untuk menjalankannya. Sepeda merupakan salah satu alat transportasi yang paling penting di dubia, karena selain rama lingkungan sepeda juga menjadi tonggak munculnya kendaraan-kendaraan lainnya. (Kurnia,2015).

Berolahraga adalah bagian dari hidup sehat dan rasa bahagia dari setiap manusia saat ini (Nenad Suzic, 2011). Bersepeda juga memenuhi tambahan aerobic yang diperlukan bagi sistem jantung tetapi dengan tekanan yang kurang terhadap anggota tubuh (Faisal Kusuma Hadi).

Sepeda pertama kali diperkenalkan di Eropa sekitar akhir abad ke-19, setelah itu mulai menyebar hingga ke Amerika Serikat dan kini hamper ke seluruh dunia. Latihan ini dikenal sebagai salah satu bentuk olahraga yang murah dan bisa memberikan banyak manfaat bagi tubuh (Fatkurahman Arjuna).

Dalam situasi pandemi ini, orang-orang memiliki ketakutan yang sama untuk terinfeksi oleh penyakit yang tidak dapat disembuhkan yaitu Covid-19. Ini memaksa orang-orang untuk mengunci diri di rumah mereka dengan harapan mereka diselamatkan dan terlindung dari infeksi virus. Padahal tinggal di rumah membuat mereka merasa aman dari infeksi tetapi ini tidak berarti bahwa mereka boleh mengunci diri di rumah. Bahkan mereka merasa bosan dengan larangan pergi kemana-mana, ditambah lagi kondisi ini sudah berlangsung terlalu lama. Jadi, orang-orang mulai melakukannya membuat berbagai macam trend selama ini, itulah sebabnya bersepeda mengalami peningkatan yang cukup signifikan. Tren bersepeda sudah menyebar ke berbagai kalangan masyarakat di kota-kota di Indonesia. Tren ini menyerang berbagai kalangan usia, dari anak-anak hingga lansia. Mereka menyukai tren bersepeda ini karena mereka berpikir bahwa bersepeda bisa menghilangkan rasa bosan namun mereka selalu bisa menjaga jarak antara lain. Ini adalah mengapa mereka memilih bersepeda. (Irham Ramdani,2020).

Motivasi telah menjadi topik utama secara umumpsikologi selama beberapa dekade, sebagaiserta baru-baru ini dalam olahraga dan olahraga psikologi. Begitu pula minat yang besartelah ditunjukkan dalam aktivitas fisik remaja, baikdari sudut pandang keterlibatan olahraga dankinerja ataupun aktivitas untuk kesehatan. Beragam surveinasional tersedia untuk mengidentifikasi alasan anak-anakdan pemuda memberi untuk partisipasi atau nonpartisipasidalam olahraga dan tampaknya ada banyak sekalialasan mengapa anak-anak dan remaja dapat mengambil bagian atauhentikan keterlibatan mereka. (Christopher M. Spray dkk, 2006).

Pada dasarnya seseorang dalam melakukan kegiatan atau tingkah laku selalu didasari oleh motivasi. Motivasi adalah suatu keadaan yang merupakan daya penggerak dalam diri seseorang individu untuk mendorong yang bersangkutan melakukan kegiatan-kegiatan atau aktivitas 
tertentu untuk mencapai tujuan tertentu pula. Daya penggerak ini akan menjadi aktif pada saat tertentu jika tujuan yang ingin dicapai sangat dirasakan atau dihayati (Hastria Effendi, 2016).

Motivasi juga merupakan serangkaian usaha tertentu untuk menyediakan kondisi-kondisi tertentu sehingga orang atau individu mau dan ingin melakukan sesuatu dan apabila tidak suka maka akan berusaha menghindarinya (Kasriman, 2017).

Menurut Uno (2008:1) di dalam Palasa Indra dan Eddy Marheni (2020) motivasi adalah kekuatan baik dari dalam maupun dari luar yang mendorong seseorang untuk mencapai tujuan tertentu yang telah ditetapkan sebelumnya.

Sutrisno (2010) di dalam Atradinal (2017) mengemukakan bahwa motivasi adalah faktor yang mendorong seseorang untuk melakukan suatu aktivitas tertentu, oleh karena itu motivasi sering kali diartikan pula sebagai faktor pendorong perilaku seseorang. Setiap aktivitas yang dilakukan oleh seseorang pasti memiliki suatu faktor yang mendorong aktivitas tersebut. Oleh karena itu, faktor pendorong dari seseorang untuk melakukan suatu aktivitas tertentu pada umumnya adalah kebutuhan serta keinginan orang tersebut.

Selain itu Hasan (1994) di dalam John Arwandi mengatakan bahwa motivasi adalah kekuatan yang mendukung individu untuk melakukan sesuatu yang diinginkan atau dikehendakinya.

Motivasi juga diartikan sebagai tergugahnya seseorang untuk bereaksi, untuk maksud prilaku tertentu yang terarah walaupun prilaku tersebut mungkin tidak efisien atau tidak efektif sebagaimana semestinya (Davies,2005) di dalam Hermanzoni.

Ada banyak alasan mengapa individu termotivasi untuk berpartisipasi dalam olahraga. Untuk atlet berpartisipasi dan akan terus berolahraga, menyelidiki motivasi partisipasiatlet sangat diperlukan. (Jalil Moradi, 2020).Motivasi ekstrinsik mengacu padapengejaran suatu aktivitas untuk mencapai hasil yang terpisah dari aktivitas itu sendiri. (Ian M. Taylor and Nikos Ntoumanis, 2007).

Motivasi intrinsik adalah gaya motivasi yang paling ditentukan sendiri (atau otonom). Individu yang termotivasi secara intrinsik terlibat dalam aktivitas untuk kesenangan dan kepuasan yang diperoleh dari partisipasi mereka (Aicher, T. J., Rice, J. A., \& Hambrick, M. E. 2017).

Jenis motivasi (intrinsik,identify regulasied, introjectedregulasied, regulasi eksternal dan amotivated) adalah otonom atau ditentukan sendiri dan menjelaskan bagaimana faktor sosial seperti perilaku signifikan tidak bisakah orang lain dan lingkungan sosial berdampak pada motivasi (Hein, V., \& Jõesaar, H. 2014).

Beberapa pertanyaan dalam literatur yang diajukan dalam studi tentang individu yang berpartisipasi dalam kegiatan rekreasi di nasional dan internasional adalah mengapa individu berpartisipasi dalam kegiatan ini dan mengapa mereka tidak berpartisipasi dan apa yang mendorong individu untuk berpartisipasi (Kim, H., Kim, S. and So, Y., 2012).

\section{METODE}

Jenis penelitian yang akan digunakan dalam penelitian ini adalah penelitian survei.Pada umumnya, survei menggunakan kuisioner atau angket untuk mengumpulkan data yang bersifat deskriptif kuantitatif. Penelitian deskriptif merupakan penelitian yang benar-benar hanya memaparkan apa yang terjadi dalam sebuah kanca, lapangan atau wilayah tertentu. Data yang terkumpul disklasifikasikan atau dikelompok-kelompokkan menurut jenis, sifat, atau kondisinya. Sesudah data yang lengkap, kemudian dibuat kesimpulan (Arikunto,2010:3).

Penelitian ini dilaksanakan di lingkungan Kecamatan Lintau Buo. Penelitian akan dilaksanakan setelah ujian proposal selesai dengan kegiatan penyebaran angket kepada sampel. Kemudian dilakukan analisis data terhadap hasil yang diperoleh dari sampel penelitian.

Populasi dalam penelitian ini adalah klub gowes Lintau Buo, yang beranggotakan 50 orang. Putri 20 orang dan putra 30 orang. Sampel dalam penelitian ini diambil dengan teknik purposive sampling yaitu mengambil sampel berdasarkan keadaan tertentu, sehingga tidak semua populasi dijadikan sampel. Pada penelitian ini hanya mengambil 
yang berjenis kelamin putra saja yang berjumlah 30 orang dikarekan, yang berjenis kelamin putri sudah lama dan tidak terlalu aktif lagi melakukan olahraga sepeda.

Sesuai dengan tujuan yang akan dicapai maka jenis data yang diperlukan dalam penelitian ini adalah data primer dan data sekunder. Data primer yang dimaksud adalah data yang langsung diperoleh oleh peneliti dari responden, berupa informasi yangdiberikan dalam menjawab pertanyaan yang berbentuk angket penelitian. Dalam hal ini, data yang dimaksud adalah "Motivasi klub gowes Lintau Buo dalam berolahraga sepeda". Sedangkan data sekundernya adalah mengenai kapan dan asal mula klub gowes Lintau Buo ini muncul.

Karena jenis penelitian ini bersifat deskriptif maka teknik analisis dapat digunakan adalah dengan menggunakan teknik distribusi frekuensi (statistic deskriptif) dengan perhitungan presentase, seperti dijelaskan Sudijono (1991 : 40) "Bila suatu penelitian bertujuan mendapatkan gambaran atau menemukan suatu sebagaimana adanya tentang suatu objek yang diteliti maka teknik analisis yang dibutuhkan cukup dengan perhitungan presentase".

Hasil Penelitian

\section{Motivasi Anggota Klub Gowes Lintau Buo dalam Olahraga Sepeda}

Secara keseluruhan motivasi pesepeda dalam mengikuti kegiatan bersepeda, peneliti memberikan 33 butir pertanyaan kepada responden. Adapun hasil dari jawaban responden terhadap pertanyaan tersebut dapat dilihat pada tabel 1 di bawah ini:

Tabel 1.Motivasi Anggota Klub Gowes Lintau Buo dalam Olahraga Sepeda

\begin{tabular}{|c|c|c|c|c|}
\hline No & Kelas Interval & Frekuensi & Persentase & Klasifikasi \\
\hline 1 & $81-100$ & 9 & $30,00 \%$ & Sangat Tinggi \\
\hline 2 & $61-80$ & 21 & $70,00 \%$ & Tinggi \\
\hline 3 & $41-60$ & 0 & $0,00 \%$ & Cukup \\
\hline 4 & $21-40$ & 0 & $0,00 \%$ & Rendah \\
\hline 5 & $0-20$ & 0 & $0,00 \%$ & Sangat Rendah \\
\hline \multicolumn{2}{|c|}{ Jumlah } & 30 & $100 \%$ & \\
\hline
\end{tabular}

Tabel 1 menunjukkan bahwa, tidak ada pesepeda yang memiliki motivasi berada pada kategori sangat rendah, rendah dan cukup dalam kegiatan bersepeda, 21 orang pesepeda yang memiliki motivasi berada pada kategori tinggi dalam kegiatan bersepeda atau sekitar 70\%, 9 orang pesepeda yang memiliki motivasi berada pada kategori sangat tinggi dalam kegiatan bersepeda atau sekitar 30\%.Jadi secara keseluruhan motivasi Anggota Klub Gowes Lintau Buo dalam olahraga sepeda, termasuk dalam kategori "Tinggi", atau sekitar $76,06 \%$.

\section{Motivasi Instrinsik}

Secara motivasi intrinsik pesepeda dalam mengikuti kegiatan bersepeda, peneliti memberikan 21 butir pertanyaan kepada responden. Adapun hasil dari jawaban responden terhadap pertanyaan tersebut dapat dilihat pada tabel 2 di bawah ini :

Tabel 2. Motivasi Intrinsik Anggota Klub Gowes Lintau Buo dalamBerolahraga Sepeda

\begin{tabular}{|l|l|l|l|l|}
\hline No & Kelas Interval & Frekuensi & Persentase & Klasifikasi \\
\hline
\end{tabular}




\begin{tabular}{|c|c|c|c|c|}
\hline & & & & \\
\hline 1 & $81-100$ & 4 & $13,33 \%$ & Sangat Tinggi \\
\hline 2 & $61-80$ & 26 & $86,67 \%$ & Tinggi \\
\hline 3 & $41-60$ & 0 & $0,00 \%$ & Cukup \\
\hline 4 & $21-40$ & 0 & $0,00 \%$ & Rendah \\
\hline 5 & $0-20$ & 0 & $0,00 \%$ & $\begin{array}{c}\text { Sangat } \\
\text { Rendah }\end{array}$ \\
\hline
\end{tabular}

Tabel 2 menunjukkan bahwa, tidakada pesepeda yang memiliki motivasi intrinsik berada pada kategori sangat rendah, rendah dan cukup dalam kegiatan bersepeda, 26 orang pesepeda yang memiliki motivasi intrinsikberada pada kategori tinggi dalam kegiatan bersepeda atau sekitar $86,67 \%, 4$ orang pesepeda yang memiliki motivasi intrinsikberada pada kategori sangat tinggi dalam kegiatan bersepeda atau sekitar 13,33\%. Jadi motivasi intrinsik Anggota Klub Gowes Lintau Buo dalam olahraga sepeda, termasuk dalam kategori "Tinggi", atau sekitar 76,16\%. Agar lebih jelasnya lihat gambar 2:



Gambar 2. Histogram Motivasi Intrinsik Anggota Klub Gowes Lintau Buo

3. Motivasi Ekstrinsik

Secara motivasi ekstrinsik pesepeda dalam mengikuti kegiatan bersepeda, peneliti memberikan 12 butir pertanyaan kepada responden. Adapun hasil dari jawaban responden terhadap pertanyaan tersebut dapat dilihat pada tabel 3 di bawah ini:

Tabel 3. Motivasi Ekstrinsik Anggota Klub Gowes Lintau Buo dalam Olahraga Sepeda

\begin{tabular}{|c|c|c|c|c|}
\hline No & Kelas Interval & Frekuennsi & Persentase & Klasifikasi \\
\hline 1 & $81-100$ & 9 & $30,00 \%$ & Sangat Tinggi \\
\hline
\end{tabular}




\begin{tabular}{|c|c|c|c|c|}
2 & $61-80$ & 21 & $70,00 \%$ & Tinggi \\
\hline 3 & $41-60$ & 0 & $0,00 \%$ & Cukup \\
\hline 4 & $21-40$ & 0 & $0,00 \%$ & Rendah \\
\hline 5 & $0-20$ & 0 & $0,00 \%$ & Sangat Rendah \\
\hline & Jumlah & 30 & $100 \%$ & \\
\hline
\end{tabular}

Tabel 3. menunjukkan bahwa, tidakada pesepeda yang memiliki motivasi ekstrinsik berada pada kategori sangat rendah, rendah dan cukup dalam kegiatan bersepeda, 21 orang pesepeda yang memiliki motivasi ekstrinsikberada pada kategori tinggi dalam kegiatan bersepeda atau sekitar 70\%, 9 orang pesepeda yang memiliki motivasi ekstrinsik berada pada kategori sangat tinggi dalam kegiatan bersepeda atau sekitar 30\%. Jadi motivasi ekstrinsik Anggota Klub Gowes Lintau Buo dalam olahraga sepeda, termasuk dalam kategori "Tinggi", atau sekitar 75,86\%. Agar lebih jelasnya lihat Gambar 3:

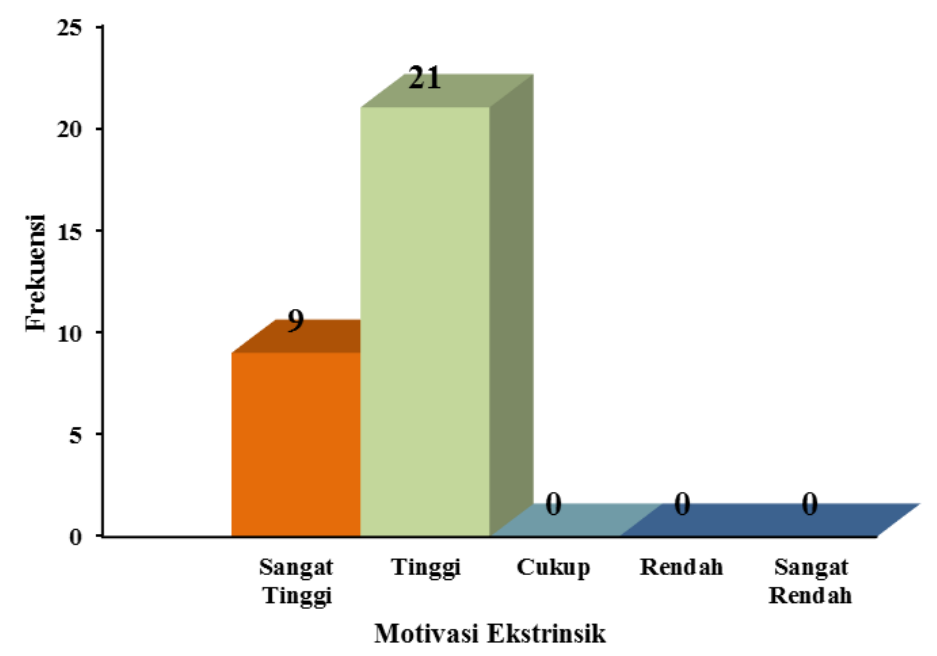

Gambar 3. Histogram Motivasi EkstrinsikAnggota Klub Gowes Lintau Buo dalam Bersepeda

\section{Pembahasan}

Berdasarkan hasil penelitian yang berjudul Motivasi Anggota Klub Gowes Lintau Buo dalam Berolahraga Sepeda, diperoleh bahwa motivasi Anggota Klub Gowes Lintau Buo dalam bersepeda berada pada kategori tinggi. Semua indikator berada pada kategori tinggi, baik motivasi intrinsik maupun ekstrinsik yang dimiliki pesepeda dalam kegiatan bersepeda. Secara umum dapat dikatakan capaian per indikator masih dibawah $81 \%$ yang berada pada golongan tinggi.

Dari hasil penelitian yang peneliti lakukan, dapat dilihat bahwa motivasi intrinsik pada anggota klub gowes Lintau Buo lebih tinggi daripada motivasi ekstrinsik. Hal ini dapat menunjukkan bahwa anggota klub gowes Lintau Buo dalam berolahraga sepeda 
semangat dan senang terhadap kegiatan yang dilakukannya. Hal ini juga menunjukkan tidak adanya paksaan tersendiri untuk anggota klub dalam melakukan kegiatan bersepeda, semua atas kesadaran dan kemauan dari anggota klub itu sendiri.

\section{KESIMPULAN}

Berdasarkan hasil penelitian, diperoleh bahwa motivasi Anggota Klub Gowes Lintau Buo dalam olahraga sepeda, secara intrinsik berada pada kategori tinggidengan tingkat capaian responden (TCR)76,16\%, dan secara ekstrinsik juga berada pada kategori tinggidengan tingkat capaian responden (TCR)75,86\%. Serta secara keseluruhan motvasi pesepeda berada pada kategori tinggi dengan tingkat capaian responden (TCR)76,06\%. Sedangkan capaian per indikator diperoleh bahwa pesepeda cenderung berada pada motivasi tinggi kategori dibawah $81 \%$ yaitu pada kedua indikator baik secara intrinsik maupun ekstrinsik.

\section{DAFTAR PUSTAKA}

Aicher, T. J., Rice, J. A., \& Hambrick, M. E. (2017). Understanding THE Relationship Between Motivation, Sport Involvement AND Sport Event Asevaluation Meanings AS Factors Influencing Marathon Participation. Journal OF Global Sport Management, 2(4), 217-233. doi:10.1080/24704067.2017.1375384

Arjuna Fatkurahman. "Menjaga Kebugaran Jasmani dengan Bersepeda". Jurnal FIK UNY. HIm. 1-12.

Arwandi, J. (2016). KONTRIBUSI MOTIVASI BERPRESTASI TERHADAP KINERJA GURU SEKOLAH DASAR NEGERI KECAMATAN PADANG UTARA. Jurnal Performa Olahraga, 1(02), 107-120. https://doi.org/10.24036/jpo79019

Atradinal, A. (2017). HUBUNGAN MOTIVASI KERJA DENGAN KINERJA GURU PENJASORKES PADANG UTARA KOTA PADANG.Jurnal Performa Olahraga, 2(02), 112-119. https://doi.org/10.24036/jpo49019

Cirrincione Luigi, dkk. (2020). "COVID-19 Pandemic: Prevention and Protection Measures to Be Adopted at the Workplace". Journal Sustainability. Hlm. 1-18.

Effendi, Hastria. (2016). "Peranan Psikologi Olahraga dalam Meningkatkan Prestasi Atlet".Jurnal Ilmu Pengetahuan Sosial. Vol. 1. Hlm. 1-9.

Hadi, Faisal Kusuma. (2020). "Aktivitas Olahraga Bersepeda Masyarakat di Kabupaten Malang Pada Masa Pandemi Covid-19".Jurnal FIK(Vol. 1 Nomor 2). HIm. 1-9

HEIN, V., \& JÕESAAR, H. (2014). How perceived autonomy support from adults and peer motivational climate are related with self-determined motivation among young athletes. International journal of sport and exercise psychology, 13(3), 193204. Doi:10.1080/1612197x.2014.947304

Hermanzoni. (2016). TINJAUAN IQ DAN MOTIVASI BERPRESTASI ATLET BOLAVOLI PRAPON SUMATERA BARAT. Jurnal Performa Olahraga, 1(01), 13-26. https://doi.org/10.24036/jpo73019

Indra, P., \& Marheni, E. (2020). Pengaruh Metode Latihan dan Motivasi Berlatih terhadap Keterampilan Bermain Sepak Bola Ssb Persika Jaya Sikabau.Jurnal Performa Olahraga, 5(1), 39-47. https://doi.org/10.24036/jpo138019

Kasriman. (2017). "Motivasi Masyarakat Melakukan Olahraga Rekreasi Melalui Program Car Free Day di Jakarta".Jurnal FKIP(Vol. 2 Nomor 2). Hlm. 1-7.

Kim, H., Kim, S. and So, Y., (2012)" The Relative Importance of Performance Factors 1 in Korean Archery", 1Department of Sport Psychology, Korea National Sport University, Seoul, Korea, Journal of Strength and Conditioning Research Publish 
Lesmana, H., \& Broto, E. (2017). OLAHRAGA SEBAGAI UPAYA PREVENTIF OSTEOPOROSIS DINI.Jurnal Performa Olahraga, 2(01), 32-41. https://doi.org/10.24036/jpo65019

Moradi Jalil, dkk. (2020). "Motivation for Participation in Sports Based on Athletes in Team and Individual Sports". HIm. 14-21.

Purnomo, E. (2018). KEPRIBADIAN MAHASISWA KEPELATIHAN: PERSPEKTIF PSIKOLOGI $\begin{array}{lll}\text { OLAHRAGA.Jurnal Performa Olahraga, 3(02), } & 100 .\end{array}$ https://doi.org/10.24036/jpo27019

Ramdani Irham. (2020). "Analysis of The Cycling Trend During the Pandemic of COVID 19 Towards Small and Medium Enterprises (UMKM) Income". International Journal of Social Science and Business. (Vol.4 Nomor 4). Hlm. 528-535).

Romadhon, SA. (2016). "Motivasi dan Minat Masyarakat dalam Berolahraga Sepeda di Kota Semarang".Journal og Physical Education, Sport, Health and Recreation. Hlm. 25-28.

Supriatna, Encup. (2020). "Socio-Economic Impacts of The COVID-19 Pandemic: The Case of Bandung City". Journal of Geovernance. (Vol 5 Issue 1). HIm. 61-70.

Suzic Nenad. (2011). "STUDENTS MOTIVATION FOR SPORTS AND THEIR EVALUATION OF SCHOOL". (Vol. 7 Nomor 1). Hlm. 35-44.

Spray, CM, dkk. (2006). "Understanding motivation in sport: An experimental test of achievement goal and self determination theories". European Journal of Sport Science. (Vol.6 Nomor 1). Hlm. 43-51.

Taylor M Ian dan Ntoumanis Niko. (2007). "Teacher Motivational Strategies and Student Self-Determination in Physical Education". Journal of Educational Psychology. (Vol. 99 Nomor 44). HIm. 747-760. 